\title{
Pelatihan Pengembangan Bahan Ajar Multimedia dalam Meningkatkan Kompetensi Guru di Desa Anrihua Kab. Bulukumba
}

\author{
Akram*1, Nurindah $^{2}$, Nasir ${ }^{3}$ \\ 1,2,3Program Studi Teknologi Pendidikan, Fakultas Keguruan dan Ilmu Pendidikan, Universitas \\ Muhammadiyah Makassar, Indonesia \\ *e-mail: $\underline{\text { akram@unismuh.ac.id }}^{1}$, nurindah@unismuh.ac.id ${ }^{2}$
}

\begin{abstract}
Abstrak
Perkembangan Teknologi informasi telah merambat ke segala bidang termasuk di bidang pendidikan, sehingga menuntut sumber daya manusia untuk mampu bersaing dan kreatif dalam memanfaatkan teknologi informasi tersebut untuk meningkatkan kompetensi dalam bidang pendidikan. Bahan ajar berbasis Multimedia merupakan sesuatu yang baru bagi guru-guru di desa anrihua kab. Bulukumba. Selama ini guru hanya memanfaatkan teknologi dalam bentuk software microsoft powerpoint hanya sebagai media presentasi materi pelajaran sehingga tidak memungkinkan bagi siswa untuk menggali pengetahuan lebih dalam terhadap bahan ajar yang telah disajikan dalam bentuk media presentasi. pengembangan bahan ajar berbasis multimedia diharapkan dapat menjadi solusi dalam memecahkan masalah tersebut khususnya di Sekolah-sekolah yang berada di desa Anrihua Kecamatan Kindang Kabupaten Bulukumba Provinsi Sulawesi Selatan. Berdasarkan hasil dari capaian materi, peserta sangat memahami apa yang disampaikan oleh penyaji dan mampu membuat bahan ajar berbasis multimediaseseuai sub pokok bahasan yang dikuasai. Selain itu peserta semakin termotivasi untuk mengembangkan bahan ajar berbasis multimedia.
\end{abstract}

Kata kunci: Kompetensi Guru, Multimedia, Pelatihan, Pengembangan Bahan Ajar

\begin{abstract}
The development of information technology has spread to all fields, including in the field of education, thus demanding human resources to be able to compete and be creative in utilizing information technology to increase competence in the field of education. Multimedia-based teaching materials are something new for teachers in Anrihua Village, Kab. Bulukumba. So far, teachers have only used technology in the form of Microsoft PowerPoint software only as a medium for presenting subject matter so that it is not possible for students to explore deeper knowledge of teaching materials that have been presented in the form of presentation media. The development of multimedia-based teaching materials is expected to be a solution in solving these problems, especially in schools located in Anrihua Village, Kindang District, Bulukumba Regency, South Sulawesi Province. Based on the results of the material achievements, participants really understand what is conveyed by the presenter and able to make multimedia-based teaching materials according to the sub-subjects mastered. In addition, participants are increasingly motivated to develop multimedia-based teaching materials.
\end{abstract}

Keywords: Development of Teaching Materials, Multimedia, Teacher Competence, Training

\section{PENDAHULUAN}

Perkembangan Teknologi informasi telah merambat ke segala bidang termasuk di bidang pendidikan, sehingga menuntut sumber daya manusia untuk mampu bersaing dan kreatif dalam memanfaatkan teknologi informasi tersebut untuk meningkatkan kompetensi dalam bidang pendidikan. Kebijakan tentang pemanfaatan teknologi dalam proses pembelajaran ataupun untuk mengembangkan diri merupakan bagian dari kompetensi pedagogik dan profesional yang harus dimiliki oleh seorang guru, hal ini tertuang dalam Peraturan Menteri Pendidikan Nasional nomor 16 tahun 2007 tentang kualifikasi dan kompetensi guru.

Kompetensi guru juga sangat tergantung pada berbagai pelatihan yang mereka ikuti (S, 2014). Guru harus terus belajar, mengikuti kegiatan ilmiah seperti pelatihan, seminar, lokakarya untuk menambah wawasan, meningkatkan pengalaman dan menerapkannya dalam kegiatan belajar mengajar. 
Berbagai media pembelajaran telah diupayakan penggunaannya baik berupa media konvensional maupun pengembangan media untuk mencapai tujuan pembelajaran.

Media merupakan alat bantu yang digunakan untuk menyalurkan pesan atau informasi. Sedangkan multimedia diartikan sebagai kumpulan beberapa media yang secara umum dapat mengkombinasikan tiga elemen yaitu suara, gambar dan teks yang memungkinkan penggunaan grafik, video, animasi, simulasi dan audio sehingga menjadi alat presentasi interaktif yang menarik dalam pembelajaran secara offline (Suyanto, 2015). Pemanfaatan teknologi dalam pembelajaran mampu menjalin interektivitas siswa terhadap media pembelajaran dalam upaya membangun pengetahuan mereka sendiri. Dalam kegiatan pembelajaran, pemanfaatan teknologi berupa penggunaan Multimedia Pembelajaran Interaktif (MPI) berbantuan komputer (Computer Assisted Intsruction) (Heru \& Yuliani R, 2020).

Bahan ajar berbasis Multimedia merupakan sesuatu yang baru bagi guru-guru di desa anrihua kab. Bulukumba. Selama ini guru hanya memanfaatkan teknologi dalam bentuk software microsoft powerpoint hanya sebagai media presentasi materi pelajaran sehingga tidak memungkinkan bagi siswa untuk menggali pengetahuan lebih dalam terhadap bahan ajar yang telah disajikan dalam bentuk media presentasi.

Pelatihan bahan ajar berbasis multimedia kepada guru sangat diperlukan untuk mendukung dan memanfaatkan secara efektif dalam proses pembelajaran secara daring. pengembangan bahan ajar berbasis multimedia diharapkan dapat menjadi solusi dalam memecahkan masalah tersebut khususnya di Sekolah-sekolah yang berada di desa Anrihua Kecamatan Kindang Kabupaten Bulukumba Provinsi Sulawesi Selatan. memiliki sejumlah sekolah mulai dari jenjang TK hingga SMP/Mts.

\section{METODE}

Kegiatan "Pelatihan Pengembangan Bahan Ajar Multimedia" ini merupakan pengabdian kepada masyarakat yang dilaksanakan menggunakan metode pelatihan kepada guru-guru se Desa Anrihua Kecamatan Kindang Kab. Bulukumba. Pelaksanaan kegiatan ini dilaksanakan selama 2 hari. Materi pelatihan disusun secara sistematis agar peserta dapat dengan mudah memahami materi yang diberikan.

Adapun beberapa tahapan yang dilalui dalam pelaksanaan pengabdian ini dibagi menjadi tiga tahapan, pertama adalah persiapan, kedua pelaksanaan, dan ketiga adalah evaluasi dan laporan. Masing-masing tahapan diuraikan sebagai berikut.

Pada tahap persiapan kami melakukan koordinasi Kepala Desa Anrihua. Koordinasi dilakukan sekaligus sebagai observasi dan mengidentifikasi permasalahan yang dihadapi oleh guru-guru dalam melaksanakan proses pembelajaran selama pandemi COVID 19. Akhirnya ditemukan permasalahan bahwa guru-guru di Desa Anrihua perlu dibekali kompetensi dalam pengembangan bahan ajar yang berbasis multimedia, dalam hal ini sekolah/madrasah se Desa Anrihua Kecamatan Kindang Kab. Bulukumba.

Setelah tim pengabdian menemukan permasalahan yang dihadapi oleh mitra, maka tim menyusun maping, mengidentifikasi masalah secara spesifik. Secara spesifik masalah yang akan diselesaikan adalah kompetensi guru dalam mengembangkan bahan ajar berbasis multimedia.

Selanjutnya tahap pelaksanaan kegiatan yang dilaksanakan pada tanggal 27-28 Oktober 2021. Kegiatan pelatihan pengembangan bahan ajar berbasis multimedia ini dilaksanakan di ruang pertemuan kantor Desa Anrihua dan adapun materi yang disajikan mengenai pengembangan bahan ajar dan multimedia pembelajaran.

Pada Tahap akhir yaitu tahap evaluasi dan laporan, kami melakukan evaluasi setelah materi disampaikan oleh narasumber menggunakan lembaran angket yang dibagikan dan sebagai tindak lanjut dari hasil evaluasi, kami terus melakukan komunikasi dengan mitra untuk mengetahui tingkat perkembangan kompetensi guru setelah mengikuti pelatihan sebagai laporan akhir. 


\section{HASIL DAN PEMBAHASAN}

Berdasarkan hasil identifikasi masalah yang ditemukan saat observasi awal dalam pelaksanaan pengabdian yaitu kurangnya kompetensi guru dalam pengembangan bahan ajar berbasis multimedia, sehingga dalam kegiatan pengabdian ini ada 2 materi yang diberikan kepada guru yaitu pemahaman tentang pengembangan bahan ajar dan pengenalan bentuk multimedia pembelajaran serta melatih dan mendampingi guru dalam mengembangkan bahan ajar berbasis multimedia.

\subsection{Pengembangan Bahan Ajar}

Langkah-langkah pengembangan bahan ajar yang didasarkan pada pendapat (Prastowo, 2013) yaitu: (1) judul diturunkan dari Kompetensi Dasar atau materi pokok sesuai dengan besar kecilnya materi; (2) petunjuk pembelajaran dituliskan secara jelas, supaya peserta didik mudah dalam menggunakannya; (3) informasi pendukung dijelaskan secara jelas, padat, dan menarik dalam bentuk tertulis atau gambar diam maupun bergerak; (4) tugas-tugas ditulis dalam program interaktif; (5) penilaian dapat dilakukan terhadap hasil karya dari tugas yang diberikan pada akhir pembelajaran, yang dapat dilihat oleh pendidik melalui komputer; serta (6) gunakan berbagai macam sumber belajar yang dapat memperkaya materi.

\subsection{Multimedia Pembelajaran}

Multimedia sangat penting digunakan dalam proses pembelajaran berdasarkan pendapat (Nazalin, Muhtadi A, 2016) yaitu Penggunaan multimedia interaktif dalam pembelajaran tentunya memiliki kelebihan yaitu: (1) sistem pembelajaran lebih inovatif dan interaktif; (2) pendidik akan selalu dituntut untuk kreatif dan inovatif dalam mencari terobosan pembelajaran; (3) mampu menggabungkan antara teks, gambar, audio, musik, animasi gambar atau video dalam suatu kesatuan yang saling mendukung guna tercapainya tujuan pembelajaran; (4) menambah motivasi peserta didik selama proses belajar mengajar hingga didapatkan tujuan pembelajaran yang diinginkan; (5) mampu menvisualisasikan materi yang selama ini sulit untuk diterangkan hanya sekedar dengan penjelasan atau alat peraga yang konvensional; dan (6) melatih peserta didik lebih mandiri dalam mendapatkan ilmu pengetahuan.

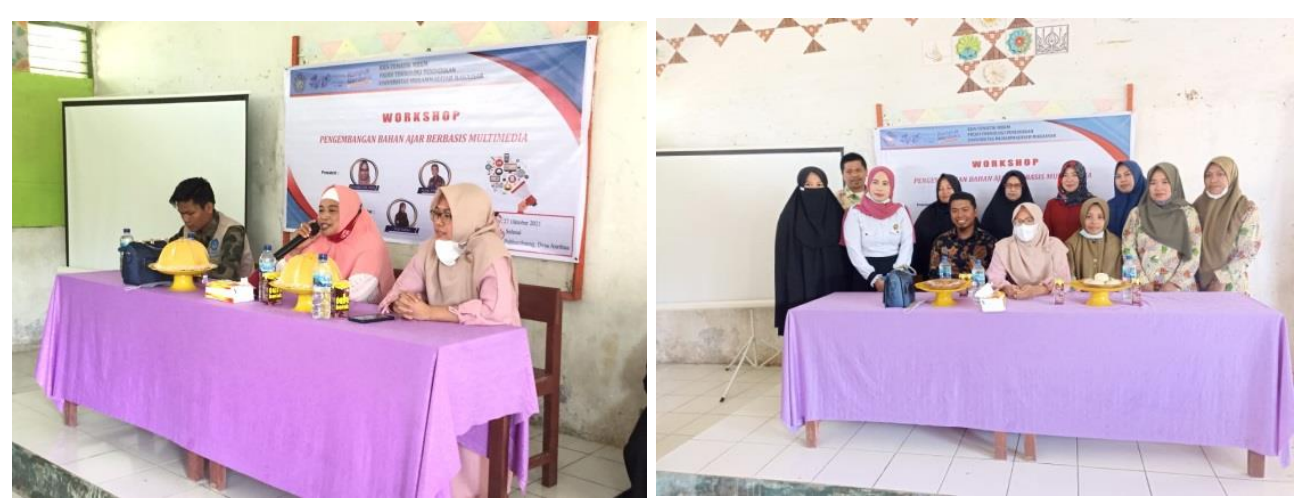

Gambar 1. Tim Memberikan Materi dalam Pelatihan Pengembangan Bahan Ajar

Setelah pemaparan materi tersebut, pemateri melanjutkan tentang cara/tutorial penggunaan dari multimedia. tahap ini setiap peserta melakukan aktivitas mempraktekkan cara membuat bahan ajar pada sub pokok bahasan yang dikuasai, dalam tahap pelaksanaan terjadi interaksi yang aktif antara pemateri dan peserta, terlihat dengan adanya tanya jawab dan antusias dari peserta.

Berdasarkan review hasil tugas pembuatan bahan ajar berbasis multimedia yang telah diberikan kepada peserta didapat hasil bahwa $100 \%$ peserta berhasil membuat bahan ajar berbasis multimedia. Sebelum kegiatan berakhir tim pengabdian meminta peserta untuk mengisi kuesioner untuk melihat kebermanfaatan dan sebagai bahan evaluasi dalam penyampaian materi untuk kegiatan tersebut. 


\section{KESIMPULAN}

Setelah berbagai rangkaian kegiatan pengabdian yang dilakukan dapat disimpulkan bahwa peserta kegiatan pengembangan bahan ajar berbasis multimedia sangat antusias, dan selama kegiatan berlangsung peserta sangat interaktif memberikan pertanyaan kepada narasumber. Narasumber menyampaikan materi berdasarkan fakta yang terjadi dilokasi sehingga sajian materi sangat aktual. Berdasarkan hasil dari capaian materi, peserta sangat memahami apa yang disampaikan oleh penyaji dan mampu membuat bahan ajar berbasis multimedia. Selain itu peserta semakin termotivasi untuk mengembangkan bahan ajar berbasis multimedia. Kedepan program serupa baik untuk dilanjutkan sebagai wujud meningkatkan kompetensi guru dalam mengembangkan bahan ajar lainnya.

\section{DAFTAR PUSTAKA}

Heru \& Yuliani R. (2020). Pelatihan pengembangan bahan ajar multimedia pembelajaran interaktif berbasis pendekatan saintifik menggunakan metode blended learning bagi guruSMP/MTs Muhammadiyah Palembang. Jurnal Pengabdian Pada Masyarakat, 5(1), 3544.

Nazalin, Muhtadi A. (2016). Pengembangan Multimedia Interaktif Pembelajaran Kimia Pada Materi Hidrokarbon Untuk Siswa Kelas XI SMA. Jurnal Inovasi Teknologi Pendidikan, 3(2), 221-236.

Prastowo. (2013). Pengembangan Bahan Ajar. Jakarta: Rajawali Press.

S, S. (2014). Teaching Competency, Profesional Commitment and Job Satisfaction-A Study of Primary School Teacher. IOSR Journal of Research \& Method in Education, 4(3), 44-64.

Suyanto. (2015). Metodologi Penelitian Cross Sectional. Klaten: Bossscript. 